\title{
IMPLEMENTASI PEMBELAJARAN STAD BERBANTU PERMAINAN ULAR TANGGA UNTUK MENINGKATKAN AKTIVITAS DAN PRESTASI BELAJAR AKUNTANSI
}

\section{THE IMPLEMENTATION OF STAD USING SNAKES \& LADDERS GAME TO IMPROVE STUDENTS'ACTIVITY AND LEARNING ACHIEVEMENT IN ACCOUNTING}

\author{
Oleh: \\ Hindun Fatmawati \\ Prodi Pendidikan Akuntansi Universitas Negeri Yogyakarta \\ hindun.fatmawati@gmail.com
}

\begin{abstract}
Abstrak
Penelitian ini bertujuan Meningkatkan Aktivitas dan Prestasi Belajar Akuntansi Ranah Kognitif serta mengetahui respon siswa kelas XI Akuntansi 3 SMK Negeri 1 Godean Tahun Ajaran 2013/2014 melalui penerapan Pembelajaran STAD Berbantu Permainan Ular Tangga. Penelitian ini merupakan penelitian tindakan kelas dengan kolaborasi yang dilakukan selama dua siklus. Materi yang disampaikan yaitu Kompetensi Dasar Pengelolaan Kartu dan Data Mutasi Aktiva Tetap. Teknik pengumpulan data melalui observasi partisipatif, tes dan angket. Instrumen penelitian yaitu dokumentasi, catatan lapangan, lembar observasi, tes dan angket. Analisis data menggunakan analisis data deskriptif kuantitatif dan kualitatif. Hasil penelitian dapat meningkatkan Aktivitas dan Prestasi Belajar Akuntansi Ranah Kognitif siswa. Rata-rata persentase Aktivitas Belajar Akuntansi sebesar $82,74 \%$ pada siklus I meningkat $13,70 \%$ menjadi $94,08 \%$ pada siklus II. Prestasi Belajar Akuntansi Ranah Kognitif siklus I rata-rata 82,47 meningkat 10,54\% menjadi 91,17 pada siklus II. Sementara itu respon siswa terhadap tindakan termasuk pada kategori setuju dengan skor klasikal sebesar $88,83 \%$.
\end{abstract}

Kata kunci: Pembelajaran STAD Berbantu Permainan Ular Tangga, Aktivitas Belajar Akuntansi, Prestasi Belajar Akuntansi Ranah Kognitif

\begin{abstract}
This study aims to improve students' activity and learning achievement of accounting in the cognitive field as well as to find out the response of the students of grade XI Akuntansi 3 SMK N 1 Godean in the academic year 2013/2014 through the implementation of STAD learning model using snakes \& ladders game. This study belongs to classroom action research with collaboration which was done in two cycles. The materials given were the basic competencies of Pengelolaan Kartu and Data Mutasi Aktiva Tetap. The data collection technique was done by doing partisipative observation, test and questionnaires. The instruments of this study are documentation, field notes, observation sheet, tests, and questionnaries. The data analysis used quantitative and qualitative descriptive analysis. The research finding shows that the model and media can improve students' activity and learning achievement of accounting in their cognitive field. The average percentage of students's learning activity in accounting was $82.74 \%$ in the first cycle and there was an increase of $13.70 \%$ to $94.08 \%$ in the second cycle. The learning achievement in the cognitive field in cycle 1 was $82,57 \%$ and it increased by $10.54 \%$ to $91.17 \%$ in cylce 2. Meanwhile, the students' response to the action came to an agreement with classical score at $88.3 \%$.
\end{abstract}

Keywords: STAD Model using Snakes \& Ladders Game, Learning Activity of Accounting, Learning Achievement of Accounting in the Cognitive Field 


\section{PENDAHULUAN}

Pendidikan merupakan usaha sadar dan terencana untuk mewujudkan suasana pembelajaran yang mendorong siswa aktif mengembangkan potensi dirinya dengan ditanamkan pengetahuan, nilai-nilai, dan keterampilan yang dilaksanakan di dalam maupun di luar lembaga formal. Tujuan pendidikan tersebut terdapat dalam Undang-Undang Republik Indonesia No. 20 Tahun 2003 tentang Sistem Pendidikan Nasional, bahwa "... bertujuan untuk berkembangnya potensi peserta didik agar menjadi manusia yang beriman dan bertakwa kepada Tuhan Yang Maha Esa, berakhlak mulia, sehat, berilmu, cakap, kreatif, mandiri, dan menjadi warga negara yang demokratis serta bertanggung jawab".

Proses pendidikan melibatkan banyak hal, Sucipto (2010) menyatakan unsur pendidikan terdiri dari peserta didik, pendidik, interaksi edukatif, tujuan pendidikan, materi pendidikan, alat dan metode, serta lingkungan pendidikan. Pelaksanaan proses pembelajaran yang ideal tidak terlepas dari unsur utama pendidikan.

Proses belajar siswa di dalam kelas untuk mendapatkan pengetahuan disebut dengan Aktivitas Belajar. Sardiman A.M. (2012: 95-96) menjelaskan mengenai konsep aktivitas dalam belajar, bahwa tidak ada belajar pada dasarnya merupakan aktivitas untuk mendapatkan pengetahuan, sikap, dan keterampilan. Martinis Yamin (2007: 77) menyebutkan pentingnya aktivitas dalam belajar bahwa "Keaktivan siswa dalam proses pembelajaran dapat merangsang dan mengembangkan bakat yang dimilikinya, berpikir kritis, dan dapat memecahkan permasalahan-permasalahan dalam kehidupan sehari-hari”.

Hasil belajar siswa yang merupakan tujuan utama pembelajaran disebut Prestasi Belajar Siswa. Syaiful Bahri (2012: 23) mengemukakan bahwa "prestasi adalah hasil yang diperoleh berupa kesan-kesan yang mengakibatkan perubahan dalam diri individu sebagai hasil dari aktivitas belajar". Prestasi Belajar menurut Benyamin Bloom terdiri dari tiga ranah, yaitu kognitif, afektif, dan psikomotor (Nana Sudjana. 2012: 22).

Proses pembelajaran di Indonesia masih terdapat masalah, dimana masalah terpenting yaitu belum sepenuhnya melibatkan peran siswa. Kesenjangan pada pelaksanaan proses pembelajaran tersebut lebih dikarenakan kurang adanya variasi model dan media pembelajaran yang diterapkan oleh guru, dimana menurut Kepala Program Studi Pendidikan Bahasa Inggris Universitas Muhammadiyah Yogyakarta, Endro Dwi Hatmanto, M.A. pada seminar Penguasaan Teori Konstruktivisme dalam Metode Pengajaran untuk Guru dan Dosen (2011), sebagian besar guru masih hanya menerapkan pembelajaran konvensional. Guru seharusnya dapat melaksanakan model pembelajaran yang mengaktifkan siswa untuk belajar terutama di kelas karena Aktivitas Belajar merupakan indikator penting dalam keberhasilan belajar siswa, dimana penilaian keberhasilan siswa dalam belajar bukan hanya diukur dari evaluasi akhir saja, namun juga harus memperhatikan proses siswa dalam mengikuti pembelajaran.

Adanya permasalahan proses pembelajaran di kelas juga terjadi di SMK Negeri 1 Godean. Berdasarkan 
pengamatan yang dilakukan pada tanggal 19 Oktober 2013, peneliti memperoleh data bahwa siswa XI AK 3 cenderung pasif apabila dibandingkan dengan kelas lainnya. Saat proses pembelajaran berlangsung siswa terlihat kurang aktif dengan persentase 46,67\%. Kurang aktifnya siswa saat belajar terlihat dari siswa berbicara hal di luar materi dengan teman, kurang aktif berbicara dan menjawab pertanyaan guru, dan kurang fokus memperhatikan penjelasan guru. Prestasi Belajar siswa juga terlihat belum maksimal, dimana pada pembelajaran akuntansi keuangan, nilai siswa masih cukup banyak yang belum mencapai KKM.

Permasalahan tersebut perlu diperbaiki melalui penggunaan model dan media pembelajaran yang lebih bervariasi, aktif dan menyenangkan. Model pembelajaran tersebut dikenal dengan model pembelajaran kelompok atau Model Pembelajaran Kooperatif. Salah satu Model Pembelajaran Kooperatif yaitu Student Teams Achievement Division (STAD). Model Pembelajaran Kooperatif ini merupakan model yang paling sederhana dan yang paling baik untuk permulaan bagi para guru yang baru menggunakan pendekatan kooperatif (Slavin, 2010: 143).

Sedangkan pemecahan masalah yang berkaitan dengan penggunaan media pembelajaran dapat digunakan media pembelajaran berupa permainan edukatif. Media pembelajaran permainan yang tepat tersebut yaitu inovasi Permainan Ular Tangga. Menurut Arief S. Sadiman (2011: 78) sebagai media pendidikan, permainan mempunyai kelebihan yaitu memungkinkan adanya partisipasi aktif dari siswa untuk belajar.

Penelitian kolaborasi ini memiliki peran yang penting untuk meningkatkan mutu pembelajaran di sekolah. Adanya peningkatan mutu pembelajaran di sekolah tertentu diharapkan dapat memotivasi sekolah lainnya untuk terus berkembang, sehingga pada akhirnya dapat berpengaruh juga pada meningkatnya mutu pendidikan Indonesia secara keseluruhan, walaupun kualitas mutu pendidikan juga harus didukung oleh unsur lainnya.

Sesuai dengan analisis permasalahan dan solusi pemecahan masalah tersebut, peneliti melakukan penelitian yang berjudul "Implementasi Model Pembelajaran Kooperatif Tipe Student Teams Achievement Division (STAD) Berbantu Media Permainan Ular Tangga untuk Meningkatkan Aktivitas dan Prestasi Belajar Akuntansi Kompetensi Dasar Pengelolaan Kartu dan Data Mutasi Aktiva Tetap Siswa Kelas XI Akuntansi 3 SMK Negeri 1 Godean Tahun Ajaran 2013/2014".

Tujuan penelitian yaitu meningkatkan Aktivitas Belajar Akuntansi, Prestasi Belajar Akuntansi Ranah Kognitif, dan mengetahui respon siswa terhadap Implementasi Model Pembelajaran Kooperatif Tipe Student Teams Achievement Division (STAD) Berbantu Media Permainan Ular Tangga untuk Meningkatkan Aktivitas dan Prestasi Belajar Akuntansi Kompetensi Dasar Pengelolaan Kartu dan Data Mutasi Aktiva Tetap Siswa Kelas XI Akuntansi 3 SMK Negeri 1 Godean Tahun Ajaran 2013/2014. 


\section{METODE PENELITIAN}

\section{Jenis Penelitian}

Penelitian ini merupakan penelitian tindakan kelas dengan bentuk kolaborasi bersama guru mata pelajaran dan dibantu oleh rekan peneliti lainnya.

\section{Waktu dan Tempat Penelitian}

Waktu pelaksanaan penelitian dari bulan Oktober 2013 sampai Februari 2014.

\section{Subjek dan Objek Penelitian}

Subjek dalam penelitian ini adalah siswa kelas XI Akuntansi 3 SMK Negeri 1 Godean yang berjumlah 31 siswa. Sedangkan objek penelitian adalah Aktivitas Belajar dan Prestasi Belajar Akuntansi Ranah kognitif Siswa Kelas XI Akuntansi 3 SMK Negeri 1 Godean Tahun Ajaran 2013/2014.

\section{Teknik Pengumpulan Data dan Instrumen Penelitian}

Teknik pengumpulan data pada penelitian ini menggunakan observasi partisipatif, tes, dan angket.

a. Observasi Partisipatif

Observasi partisipatif bertujuan untuk mendapatkan data mengenai profil sekolah, perangkat pembelajaran, pelaksanaan pembelajaran dan aktivitas belajar siswa pada pembelajaran sebelum tindakan, dan data prestasi belajar akuntansi siswa kelas yang dilakukan tindakan. Data mengenai profil sekolah, perangkat pembelajaran dan prestasi belajar diperoleh dari dokumentasi sekolah, sedangkan data mengenai pelaksanaan pembelajaran dan aktivitas belajar siswa pada pembelajaran sebelum tindakan diperoleh saat observasi awal. Observasi yang dilakukan pada saat penelitian bertujuan untuk memperoleh data mengenai proses pembelajaran dan tingkat Aktivitas Belajar Akuntansi siswa. Hasil pengamatan terhadap proses pembelajaran dicatat dalam catatan lapangan, sedangkan data aktivitas belajar siswa dicatat pada lembar observasi.

Indikator Aktivitas Belajar Akuntansi pada penelitian ini yaitu memperhatikan apa yang disampaikan guru, menulis dan membuat catatan materi penting, bertanya/ menjawab/ menyampaikan pendapat pada saat kegiatan belajar dan diskusi, memperhatikan proses belajar pada saat diskusi dan permainan, bekerjasama dengan teman satu tim, bertanggungjawab pada tugas dalam tim, mendiskusikan masalah dan bertukar pendapat antar anggota tim, memiliki kepedulian terhadap kesulitan yang dihadapi anggota tim, mengambil keputusan berdasarkan pertimbangan tim, dan mengerjakan pretest dan posttest dengan kemampuan sendiri.

b. Tes

Tes digunakan untuk mengukur Prestasi Belajar Akuntansi Ranah kognitif pada kemampuan pengetahuan, pemahaman, aplikasi, dan analisis siswa pada pembelajaran menggunakan Model Pembelajaran STAD Berbantu Media Permainan Ular Tangga. Jenis tes yang digunakan berupa tes pilihan ganda dan uraian. Setelah diujikan dilakukan analisis 
terhadap butir soal tes menggunakan program AnBuso versi 5.0.

c. Angket

Angket yang digunakan pada penelitian ini adalah angket tertutup yang digunakan untuk mengukur respon siswa terhadap Implementasi Model Pembelajaran Kooperatif Tipe STAD Berbantu Media Permainan Ular Tangga. Angket berisi pernyataan-pernyataan terkait Aktivitas Belajar Akuntansi siswa pada pembelajaran menggunakan Model Pembelajaran STAD Berbantu Media Permainan Ular Tangga serta pandangan siswa terhadap kelayakan penerapan Model Pembelajaran STAD Berbantu Media Ular Tangga pada proses pembelajaran Akuntansi. Angket tersebut dibagikan dan diisi oleh siswa pada siklus II.

\section{Prosedur Penelitian}

Penelitian dilaksanakan selama dua siklus yang meliputi tahap perencanaan, pelaksanaan, pengamatan, dan refleksi pada setiap siklus.

\section{Teknik Analisis Data}

a. Analisis Data Deskriptif Kuantitatif Data yang diperoleh dari lembar observasi, tes, dan angket adalah data kuantitatif. Langkah analisis data kuantitatif yaitu menentukan kriteria pemberian skor untuk hasil Aktivitas dan Prestasi Belajar Ranah Kognitif serta angket respon siswa. Setelah itu menjumlahkan skor menggunakan rumus sebagai berikut:

1) Data Aktivitas Belajar Akuntansi

Persentase skor indikator: $\%=\frac{\text { Jumlah } \text { skor setiap indikator }}{\text { Skor maksimal }} \times 100 \%$
(Sugiyono, 2012: 144)

Persentase skor setiap siswa: $\%=\frac{\text { jumlah } \text { skor aktivitas }}{\text { skor maksimal }} \times 100 \%$

Skor rata-rata secara klasikal: $=\frac{\text { Total skor setiap indikator }}{\text { skor maksimal }} \times 100 \%$

(Sugiyono, 2012: 144)

Peningkatan skor rata-rata secara klasikal pada siklus I dan II: Persentase rata - rata aktivitas siklus II-skor pada siklus I $=\frac{\text { Persentase rata }- \text { rata aktivitos pada siklus } I}{1} \times 100 \%$

2) Data Prestasi Belajar Akuntansi Ranah kognitif

Nilai pretest dan posttest: Nilai $=\frac{\text { Skor Soal Pilihan Ganda }+ \text { Skor Soal Uraian }}{6}$

Rata-rata nilai siswa pada pretest ke posttest pada masingmasing siklus:

$$
M e=\frac{\sum F x}{N}
$$

Keterangan:

Me : Rata-rata

$\sum F x \quad$ Jumlah semua nilai siswa

$N \quad$ : Jumlah siswa

Sumber: Sugiyono (2012: 49)

Ketuntasan belajar: $=\frac{\text { Jumlah Siswa yang mencapai nilai KKM }}{\text { Jumlah Siswa }} \times 100 \%$

Perbandingan siklus I dan

siklus II:

$=\frac{\text { Rata }- \text { rata nilai posttest siklus II }- \text { rata }- \text { rata nilai siklus I }}{\text { Rata }- \text { rata nilai posttest sikhus I }} \times 100 \%$

3) Angket Respon Siswa

Persentase skor respon setiap siswa:

$\%=\frac{\text { jumlah skor respon siswa }}{\text { skor maksimal }} \times 100 \%$

Persentase skor untuk masingmasing pilihan jawaban pernyataan angket: 
$\%=\frac{\text { Jumlah } \text { skor setiap pernyataan }}{\text { Skor maksimal }} \times 100 \%$

(Sugiyono, 2012: 144)

Skor rata-rata respon secara

klasikal:

$$
=\frac{\text { Total skor setiap pernyataan }}{\text { skor maksimal }} \times 100 \%
$$

(Sugiyono, 2012: 144)

Setelah skor diketahui

kemudian mendeskripsikan data dalam bentuk tabel, dan membuat kesimpulan.

b. Analisis Data Deskriptif Kualitatif

Analisis data kualitatif untuk data yang berasal dari catatan lapangan. Langkah-langkah analisis data yang dilakukan dalam penelitian ini, yaitu penyajian data dalam bentuk uraian singkat pada lembar catatan lapangan dan penarikan kesimpulan yang disajikan pada hasil penelitian terkait proses pelaksanaan pembelajaran.

\section{HASIL PENELITIAN DAN PEMBAHASAN}

\section{Aktivitas Belajar Akuntansi}

a. Indikator memperhatikan apa yang disampaikan guru

Terjadi peningkatan skor dari siklus I ke siklus II sebesar 9,54\%, dimana skor pada siklus I 86,29\% dan pada siklus II 95,83\%.

Pembelajaran Kooperatif Tipe

STAD Berbantu Media Permainan Ular Tangga mengharuskan siswa memahami apa yang disampaikan guru terutama saat presentasi materi sebagai pedoman siswa dalam menjawab kartu soal pada diskusi dan permainan serta soal posttest.
Hal tersebut sesuai dengan unsur pembelajaran Tipe STAD yang disampaikan Slavin (2010: 144) bahwa melalui presentasi guru siswa menyadari harus memperhatikan materi yang disampaikan guru supaya dalam kegiatan diskusi dan kuis individu dapat memberikan skor yang maksimal kepada timnya.

b. Indikator menulis dan membuat catatan materi penting

$$
\text { Indikator menulis dan }
$$

membuat catatan materi penting mengalami peningkatan perolehan skor dari siklus I ke II sebesar $16,61 \%$. Skor indikator pada siklus I sebesar 73,39\% sehingga belum mencapai kriteria minimal, namun pada siklus II skor meningkat menjadi 90\%. Materi pada siklus I cenderung lebih mudah dipahami, berbeda pada siklus II, materi yang dipelajari lebih kompleks dan membutuhkan penguasaan konsep dalam perhitungan, sehingga siswa lebih giat mencatat hal penting dan contoh-contoh yang disampaikan oleh guru.

Adanya peningkatan aktivitas menulis siswa sesuai dengan tujuan pembelajaran kooperatif yang disampaikan Isjoni (2012: 15-16) yaitu menjadikan siswa lebih memahami materi yang sulit serta semangat untuk berhasil. Siswa yang merasa belum memahami materi akan berusaha memahami salah satu caranya dengan mencatat hal penting yang dapat dipelajari dilain waktu supaya dapat mencapai hasil yang maksimal. 
c. Indikator bertanya, menjawab atau menyampaikan pendapat baik saat presentasi guru maupun diskusi dan permainan

Indikator ini pada siklus I hanya mencapai skor $55,65 \%$ dan belum mencapai kriteria minimal, namun pada siklus II mengalami peningkatan sebesar $21,85 \%$ sehingga skor menjadi 77,50\%. Materi yang dipelajari pada siklus I memang lebih mudah, sehingga siswa lebih aktif dalam menjawab secara serentak satu kelas namun untuk bertanya kurang. Siswa masih terlihat malu untuk menyampaikan pendapat terutama pada siklus I. Situasi berbeda pada siklus II siswa lebih aktif menyampaikan pendapatnya baik saat presentasi materi dan terutama saat diskusi. Hasil tersebut sesuai dengan keunggulan pembelajaran Tipe STAD menurut Slavin (1995) dalam Fhajar Wijayanti (2012) bahwa pembelajaran tersebut dapat meningkatkan interaksi antar siswa seiring dengan peningkatan kemampuan mereka dalam berpendapat.

d. Indikator memperhatikan proses belajar pada saat diskusi dan permainan

Pelaksanaan siklus I indikator ini mencapai skor $91,94 \%$ meningkat $3,89 \%$ sehingga menjadi $95,83 \%$. Kartu soal yang disusun terdiri dari bermacam jenis soal menjadikan siswa lebih memperhatikan diskusi dan permainan. Sesuai dengan yang disampaikan Trianto (2010: 56) bahwa melalui pembelajaran kooperatif menjadikan siswa dapat menjadi pendengar yang aktif. Tujuan digunakannya media pembelajaran menurut Gerlach dan Ely (1980) dalam Wina Sanjaya (2012: 163) yaitu dapat menciptakan kondisi yang memungkinkan siswa memperoleh pengetahuan, keterampilan, dan sikap melalui proses memperhatikan pembelajaran.

e. Indikator bekerjasama dengan teman satu tim saat diskusi dan permainan

Indikator ini pada siklus I mencapai skor sebesar $84,68 \%$ dan meningkat menjadi $98,33 \%$. Peningkatan aktivitas kerjasama antar anggota tim mengalami peningkatan sebesar 13,65\%. Pencapaian skor kerjasama saat diskusi dan permainan dilatarbelakangi oleh peraturan pembelajaran menggunakan Model Kooperatif Tipe STAD Berbantu Media Permainan Ular Tangga, dimana siswa harus bekerjasama dalam diskusi dan permainan supaya tim dapat segera menyelesaikan tugas dan mendapatkan skor yang banyak untuk timnya. Hal tersebut sesuai dengan yang disampaikan oleh Isjoni (2012: 15-16) bahwa tujuan Pembelajaran Kooperatif dirancang khusus untuk mendorong peserta didik supaya dapat bekerja sama dengan temannya selama proses pembelajaran.

f.Indikator bertanggungjawab pada tugas dalam tim saat diskusi dan permainan 
Indikator bertanggungjawab

pada tugas tim mengalami peningkatan sebesar $11,19 \%$ dari siklus I ke siklus II. Skor pada siklus I sebesar $85,48 \%$ meningkat menjadi $96,67 \%$ di siklus II. Tanggungjawab siswa terhadap tugas tim dipengaruhi oleh peraturan permainan yang mewajibkan siswa secara bergantian untuk memainkan permainan, memimpin diskusi tim, dan menjelaskan hasil jawaban kartu soal. Peningkatan aktivitas juga dipengaruhi dengan adanya penilaian terhadap tim terkompak. Hasil yang diperoleh pada indikator tersebut sesuai dengan unsur utama Model Pembelajaran Kooperatif yang disampaikan oleh Johnson \& Johnson (1994) dalam Trianto (2010: 60-61) yaitu menuntut adanya tanggung jawab individu.

g. Indikator mendiskusikan masalah dan bertukar pendapat antar anggota tim

Indikator ini pada siklus I mencapai skor 83,87\% kemudian meningkat sebesar $12,80 \%$ pada siklus II menjadi 96,67\%. Meningkatnya aktivitas siswa dalam berdiskusi dan bertukar pendapat dipengaruhi oleh peraturan pembelajaran bahwa setiap tim mendapatkan kartu soal saat permainan mereka wajib mendiskusikannya terlebih dahulu dengan teman yang lain supaya jawaban yang akan disampaikan sudah tepat. Diskusi juga ditujukan supaya siswa dapat berbagi ilmu dan memastikan anggota tim yang lain sudah memahami materinya. Perubahan positif aktivitas siswa dalam berdiskusi dan bertukar pendapat sesuai dengan unsur Pembelajaran Kooperatif Tipe STAD yang disampaikan oleh Johnson \& Johnson (1994) dalam Trianto (2010: 60-61), bahwa melalui pembelajaran kooperatif Tipe STAD dapat meningkatkan keterampilan interpersonal siswa dalam berkomunikasi dengan orang lain, bagaimana cara mereka mendengarkan dan menyampaikan pendapatnya.

h. Indikator memiliki kepedulian terhadap kesulitan memahami materi dan mengerjakan soal diskusi yang dihadapi anggota tim Pelaksanaan siklus I menghasilkan skor aktivitas siswa dalam memiliki kepedulian terhadap kesulitan memahami materi dan mengerjakan soal diskusi yang dihadapi anggota tim sebesar 82,26\%. Skor tersebut meningkat $11,07 \%$ pada siklus II sehingga skor menjadi $93,33 \%$. Indikator ini sangat berpengaruh dalam pembelajaran Tipe STAD, dimana tim yang saling memiliki kepedulian terhadap kesulitan anggota lain dalam memahami materi dan mengerjakan soal diskusi akan meningkatkan skor penilaian diskusi tim maupun individu.

Kepedulian siswa pada anggota timnya sesuai dengan yang disampaikan oleh Isjoni (2010: 74) bahwa pembelajaran Tipe STAD 
menekankan pada aktivitas dan interaksi antar anggota tim untuk saling memotivasi dan membantu dalam menguasai materi pelajaran guna mencapai prestasi yang maksimal. Hal tersebut didukung oleh pendapat Johnson \& Johnson (1994) dalam Trianto (2010: 6061) bahwa aktivitas siswa dalam membantu antar anggota tim berlangsung secara alamiah pada pembelajaran kooperatif.

i.Indikator mengambil keputusan berdasarkan pertimbangan anggota lain

Indikator ini pada siklus I mencapai skor $88,71 \%$ dan siklus II meningkat menjadi $96,67 \%$. Peningkatan skor aktivitas ini mencapai 7,96\%. Pelaksanaan Model Pembelajaran Kooperatif Tipe STAD yang menekankan bahwa siswa harus mengambil keputusan sesuai dengan kesepakatan anggota tim supaya apa yang diputuskan dapat mencapai hasil yang baik dan maksimal. Keputusan bersama dalam tim dapat berupa keputusan menjawab kartu soal yang ada dan mengatur strategi dalam permainan.

Keberhasilan peningkatan Aktivitas Belajar Akuntansi ini sesuai dengan apa yang disampaikan oleh Trianto (2010: 58) bahwa salah satu tujuan Pembelajaran Kooperatif menjadikan siswa berlatih untuk memimpin dan membuat keputusan bersama dalam kelompok.
j.Indikator mengerjakan pre dan posttest dengan kemampuan sendiri

Indikator ini yang dapat mencapai skor sempurna pada pelaksanaan kedua siklus. Siswa selalu mengerjakan pre dan posttest dengan kemampuan sendiri, sehingga skor pada kedua siklus mencapai $100 \%$. Penekanan pada Pembelajaran Kooperatif Tipe STAD supaya siswa mengerjakan soal individu secara mandiri dapat tercapai karena ditekankan bahwa siswa dapat berdiskusi dengan teman saat ada saatnya sendiri yaitu pada pelaksanaan diskusi dan permainan.

Aktivitas siswa ini sesuai dengan yang disampaikan oleh Slavin (2010: 143-146) bahwa pembelajaran Kooperatif Tipe STAD dapat menjadikan siswa bertanggung jawab secara individu untuk memahami materinya sehingga tidak saling membantu dalam mengerjakan kuis.

\section{Prestasi Belajar Akuntansi Ranah Kognitif}

Berdasarkan pelaksanaan pembelajaran menggunakan Model Pembelajaran Kooperatif Tipe Student Teams Achievement Division (STAD) Berbantu Media Permainan Ular Tangga hasil rata-rata kelas dari nilai pretest dan posttest pada setiap siklus adalah sebagai berikut: 
Tabel 1. Perbandingan Nilai Rata-rata Prestasi Belajar Siswa Secara Klasikal pada siklus I dan II

\begin{tabular}{|c|c|c|c|}
\hline \multirow{2}{*}{$\begin{array}{c}\text { Pelak- } \\
\text { sanaan }\end{array}$} & \multicolumn{2}{|c|}{ Rata-rata Nilai } & \multirow{2}{*}{$\begin{array}{c}\text { Pening- } \\
\text { katan }\end{array}$} \\
\cline { 2 - 3 } Pretest & Posttest & $123,13 \%$ \\
\hline Siklus I & 36,96 & 82,47 & $92,06 \%$ \\
\hline Siklus II & 47,47 & 91,17 & 92. \\
\hline $\begin{array}{c}\text { Pening- } \\
\text { katan }\end{array}$ & $28,44 \%$ & $\mathbf{1 0 , 5 5 \%}$ & $-25.23 \%$ \\
\hline
\end{tabular}

Ketuntasan belajar secara klasikal dilihat dari hasil posttest, dimana minimal 75\% siswa mencapai KKM SK mengelola kartu aktiva tetap yaitu 75 pada setiap siklus dan adanya peningkatan ketuntasan dari siklus I ke siklus II. Berikut ini data peningkatan ketuntasan belajar secara klasikal pada siklus I dan siklus II:

Tabel 2. Peningkatan Ketuntasan Belajar Akuntansi Ranah kognitif secara Klasikal

\begin{tabular}{|c|l|l|c|}
\hline \multirow{2}{*}{ Nilai } & \multicolumn{2}{|c|}{ Hasil Posttest } & \multirow{2}{*}{$\begin{array}{c}\text { Pening- } \\
\text { katan \% }\end{array}$} \\
\cline { 2 - 3 } & Siklus I & Siklus II & \\
\hline$\geq 75$ & $80.65 \%$ & $87.10 \%$ & $8.00 \%$ \\
\hline$<75$ & $19.35 \%$ & $12.90 \%$ & $33.33 \%$ \\
\hline
\end{tabular}

Sementara itu data Prestasi Belajar Akuntansi Ranah kognitif secara individual setiap siswa dilihat dari adanya peningkatan dari nilai pretest ke posttest pada setiap siklus.

Hasil pelaksanaan tindakan tersebut sesuai dengan pernyataan Muhibbin Syah, Isjoni, dan Arief S. Sadiman. Muhibbin Syah (2013: 129) menjelaskan faktor-faktor yang mempengaruhi Prestasi Belajar salah satunya yaitu faktor pendekatan belajar yang meliputi strategi dan metode yang digunakan dalam menyampaikan materi pada siswa. Isjoni (2012: 15-16) mengungkapkan bahwa pembelajaran kooperatif dapat meningkatkan prestasi belajar siswa, sementara itu Arief S. Sadiman dkk (2011: 17-18) menyebutkan bahwa media pendidikan berguna untuk menimbulkan kegairahan siswa dalam belajar.

\section{Angket Respon Siswa}

Dilihat dari skor rata-rata kelas, dikatakan baik apabila skor rata-rata siswa dalam menjawab angket mencapai minimal 60 atau persentase $75 \%$. Berikut ini tabel penilaian angket respon siswa dilihat dari pernyataan dan rata-rata skor kelas:

Tabel 3. Penskoran Pernyataan Angket Respon Siswa

\begin{tabular}{|c|c|}
\hline $\begin{array}{c}\text { No. } \\
\text { Pernyataan }\end{array}$ & Perhitungan \\
\hline 1. & $111 / 120 \times 100 \%=92,50 \%$ \\
\hline 2. & $110 / 120 \times 100 \%=91,67 \%$ \\
\hline 3. & $105 / 120 \times 100 \%=87,50 \%$ \\
\hline 4. & $93 / 120 \times 100 \%=77,50 \%$ \\
\hline 5. & $106 / 120 \times 100 \%=88,33 \%$ \\
\hline 6. & $117 / 120 \times 100 \%=97,50 \%$ \\
\hline 7. & $111 / 120 \times 100 \%=92,50 \%$ \\
\hline 8. & $106 / 120 \times 100 \%=88,33 \%$ \\
\hline 9. & $98 / 120 \times 100 \%=81,67 \%$ \\
\hline 10. & $111 / 120 \times 100 \%=92,50 \%$ \\
\hline 11. & $108 / 120 \times 100 \%=90,00 \%$ \\
\hline 12. & $109 / 120 \times 100 \%=90,83 \%$ \\
\hline 13. & $106 / 120 \times 100 \%=88,33 \%$ \\
\hline 14. & $95 / 120 \times 100 \%=79,17 \%$ \\
\hline 15. & $101 / 120 \times 100 \%=84,17 \%$ \\
\hline 16. & $106 / 120 \times 100 \%=88,33 \%$ \\
\hline 17. & $106 / 120 \times 100 \%=88,33 \%$ \\
\hline 18. & $115 / 120 \times 100 \%=95,83 \%$ \\
\hline 19. & $102 / 120 \times 100 \%=85,00 \%$ \\
\hline
\end{tabular}




\begin{tabular}{|c|c|}
\hline $\begin{array}{c}\text { No. } \\
\text { Pernyataan }\end{array}$ & Perhitungan \\
\hline 20. & $116 / 120 \times 100 \%=96,67 \%$ \\
\hline$=\frac{2132}{4 \times 20 \times 30} \times 100 \%=\mathbf{8 8}, \mathbf{8 3} \%$ \\
\hline
\end{tabular}

Dilihat dari skor setiap pernyataan respon yang ditetapkan sudah sesuai kriteria persentase yaitu minimal $75 \%$, sementara itu dilihat dari skor setiap siswa dalam menjawab angket sudah mencapai skor minimal $75 \%$, hal tersebut dapat disimpulkan juga bahwa jumlah siswa satu kelas dalam menjawab yang termasuk kriteria setuju sebesar $100 \%$ dan sudah mencapai kriteria minimal yang ditetapkan $75 \%$.

Implementasi

Model

Pembelajaran Kooperatif Tipe Student Teams Achievement Division (STAD) Berbantu Media Permainan Ular Tangga pada pembelajaran akuntansi Kompetensi Dasar Pengelolaan Kartu Aktiva Tetap mendapat respon yang baik dari siswa. Hal tersebut diartikan bahwa siswa merasa senang, aktif, dan semangat dalam belajar melalui diterapkannya Model Pembelajaran Kooperatif Tipe Student Teams Achievement Division (STAD) Berbantu Media Permainan Ular Tangga pada pembelajaran akuntansi.

Berdasarkan hasil penelitian menunjukkan bahwa Model Pembelajaran Kooperatif Tipe STAD Berbantu Media Permainan Ular Tangga di SMK Negeri 1 Godean kelas XI Akuntansi 3 Tahun Ajaran 2013/2014 dapat Meningkatkan Aktivitas dan Prestasi Belajar Akuntansi Ranah kognitif siswa KD Pengelolaan Kartu dan Data Mutasi Aktiva Tetap. Hal ini ditunjukkan dari hasil observasi yang menunjukkan adanya peningkatan Aktivitas Belajar Akuntansi dan posttest yang didukung dengan pretest menunjukkan hasil Prestasi Belajar Akuntansi. Sedangkan instrumen angket menunjukkan hasil respon siswa terhadap Implementasi Model Pembelajaran Kooperatif Tipe STAD Berbantu Media Permainan Ular Tangga pada pembelajaran akuntansi. Hasil penelitian juga menunjukkan bahwa penggunaan variasi model dan media pembelajaran akuntansi dapat menjadikan suasana pembelajaran yang berbeda sehingga siswa tidak merasa jenuh.

\section{SIMPULAN DAN SARAN}

1. Simpulan

a. Implementasi

Model

Pembelajaran Kooperatif Tipe

Student Teams Achievement

Division (STAD) Berbantu Media

Permainan Ular Tangga dapat

Meningkatkan Aktivitas Belajar

Akuntansi Kompetensi Dasar

Pengelolaan Kartu dan Data

Mutasi Aktiva Tetap siswa kelas

XI Akuntansi 3 SMK Negeri 1

Godean Tahun Ajaran 2013/2014.

b. Implementasi

Model

Pembelajaran Kooperatif Tipe

Student Teams Achievement

Division (STAD) Berbantu Media

Permainan Ular Tangga dapat Meningkatkan Prestasi Belajar Akuntansi Ranah Kognitif Kompetensi Dasar Pengelolaan Kartu dan Data Mutasi Aktiva Tetap siswa kelas XI Akuntansi 3 SMK Negeri 1 Godean Tahun Ajaran 2013/2014. 
c. Adanya respon baik dari siswa terhadap Implementasi Model Pembelajaran Kooperatif Tipe Student Teams Achievement Division (STAD) Berbantu Media Permainan Ular Tangga dapat Meningkatkan Aktivitas dan Prestasi Belajar Akuntansi Ranah Kognitif Kompetensi Dasar Pengelolaan Kartu dan Data Mutasi Aktiva Tetap siswa kelas XI Akuntansi 3 SMK Negeri 1 Godean Tahun Ajaran 2013/2014.

\section{Saran}

a. Bagi Guru

1) Guru hendaknya melakukan variasi dalam penggunaan model dan media pembelajaran agar siswa tidak merasa bosan.

2) Guru sebaiknya lebih meningkatkan Aktivitas dan Prestasi Belajar Akuntansi siswa, salah satunya dengan belajar berkelompok dan pemberian hadiah bagi kelomok terbaik.

b. Bagi Siswa

1) Setiap siswa sebaiknya memiliki dan meningkatkan Aktivitas serta Prestasi Belajar Akuntansi mereka.

2) Siswa seharusnya lebih percaya diri untuk menjawab dan menyampaikan pendapat

c. Bagi Penelitian Selanjutnya

1) Lebih meningkatkan inovasi terhadap Implementasi Metode Model Pembelajaran Kooperatif Tipe STAD Berbantu Media Permainan Ular Tangga.
2) Pelaksanaan penelitian dapat mengukur prestasi belajar yang lainnya yaitu ranah afektif dan psikomotor.

3) Diharapkan dapat menyusun butir soal yang lebih baik.

\section{DAFTAR PUSTAKA}

Arief S. Sadiman, dkk. (2011). Media Pendidikan. Jakarta: PT RajaGrafindo Persada.

Fhajar Wijayanti. (2012). Model Pembelajaran Kooperatif Student Teams Achievement Division (STAD). Diambil dari http://fhajarwijayanthiviolet.blo gspot.com $/ 2012 / 02 /$ modelpembelajaran-kooperatifstudent.html, pada tanggal 13 Juni 2013, pukul 22.00 WIB).

Isjoni. (2010). Pembelajaran Kooperatif. Yogyakarta: Pustaka Pelajar.

Martinis Yamin. (2007). Kiat Membelajarkan Siswa. Jakarta: Gaung Persada Press.

Muhibbin Syah. (2013). Psikologi Pendidikan. Bandung: PT Remaja Rosdakarya.

Nana Sudjana. (2012). Penilaian Hasil Proses Belajar Mengajar. Bandung: PT Remaja Rosdakarya.

Slavin, Robert E. (2010). Cooperative Learning. Bandung: Nusa Media.

Sucipto. (2010). Pengertian dan Unsurunsur Pendidikan. Diambil dari http://sucipto.guru.fkip.uns.ac.id /2010/01/06/pengertian-dan- 
unsur-unsur-pendidikan-2/, pada tanggal 7 Oktober 2013, pukul 14.04 WIB).

Syaiful Bahri Djamarah. (2012). Prestasi Belajar dan Kompetensi Guru. Surabaya: Usaha Nasional.

UMY News. (2011). Metode Pembelajaran Konvensional Sebabkan Siswa Kurang berpikir Kritis. Seminar Penguasaan Teori Konstruktivisme dalam Metode Pengajaran untuk Guru dan Dosen. Diambil dari http://www.umy.ac.id/metodepengajaran-konvensionalsebabkan-siswa-kurangberpikir-kritis.html, pada tanggal 1 Oktober 2013, pukul 07.40 WIB.

Trianto. (2010). Mendesain Model Pembelajaran InovativeProgresif. Jakarta: Prenada Media Group.

Undang-Undang. Diambil dari http://www.menkokesra.go.id/n ode/337, pada tanggal 15 Desember 2013, pukul 23.07 WIB.

Wina Sanjaya. (2012). Strategi Pembelajaran Berorientasi Standar Proses Pendidikan. Jakarta: Kencana. 